Internal and external R\&D: complements or substitutes? Evidence from a dynamic panel data model

Boris Lokshin, René Belderbos and Martin Carree

DEPARTMENT OF MANAGERIAL ECONOMICS, STRATEGY AND INNOVATION (MSI) 


\title{
Internal and external R\&D: complements or substitutes? Evidence from a dynamic panel data model
}

\author{
Boris Lokshin $^{\mathrm{a}^{*}}$, René Belderbos ${ }^{\mathrm{b}, \mathrm{c}}$, Martin Carree $^{\mathrm{a}}$ \\ ${ }^{\mathrm{a}}$ Faculty of Economics and Business Administration, University of Maastricht, $P O$ Box 616, \\ 6200 MD Maastricht, The Netherlands \\ ${ }^{\mathrm{b}}$ Faculty of Economics and Applied Economics, Katholieke Universiteit Leuven \\ Naamsestraat 69, B-3000 Leuven, Belgium \\ ${ }^{\mathrm{c}}$ Faculty of Technology Management, Eindhoven University of Technology, The Netherlands
}

\begin{abstract}
We examine the impact of internal and external R\&D on labor productivity in a 6-year panel of 304 innovating firms. We apply a dynamic linear panel data model that allows for decreasing returns to scale in internal and external R\&D with a non-linear approximation of changes in the knowledge stock. We find complementarity between internal and external R\&D, with a positive impact of external R\&D only evident in case of sufficient internal R\&D. The findings confirm the role of internal $R \& D$ in enhancing absorptive capacity and hence the effective utilization of external knowledge. These results suggest that empirical studies examining complementarities between continuously measured practices should adopt more general non-linear specifications to allow for correct inferences.
\end{abstract}

Acknowledgements: The empirical part of this research uses micro-level data provided by CEREM/Statistics Netherlands, drawing on the MICRONOOM data integration project at Statistics Netherlands supervised by Bert Diederen. The views expressed in this paper are those of the author and do not necessarily reflect the policies of Statistics Netherlands. We are grateful to Pierre Mohnen and participants of the 2005 EARIE conference in Porto for comments on an earlier draft.

Keywords: R\&D, Innovation, Complementarity, Dynamic panel data, Productivity

JEL classification: O32, O33, D24

\footnotetext{
${ }^{*}$ Corresponding author. E-mail address: B.Lokshin@os.unimaas.nl
} 


\section{Introduction}

Since the seminal contribution of Milgrom and Roberts (1990), research in the fields of industrial organization and management has devoted renewed attention to the investigation of complementary relations between organizational practices. ${ }^{2}$ Complementarity is understood in this context to exist if the implementation of one practice increases the marginal return to other practices. One relevant application that has received substantial attention is the complementarity between in-house R\&D expenditures and external technology sourcing. It has been argued that in-house R\&D has 'two faces': it has a direct performance effect and at the same time it enhances the effectiveness of external technology sourcing by providing the means to understand and utilize the externally acquired information (Cohen and Levinthal, 1989; Griffith et al., 2003; 2004). ${ }^{3}$ At the same time, studies suggest that the importance of external R\&D has been increasing in recent years (e.g. Bönte, 2003).

However, empirical studies of the complementarity between internal and external R\&D have produced mixed findings. Arora and Gambardella (1990) suggest complementarity between in-house $R \& D$ and external $R \& D$ in the form of alliances and equity participations in $R \& D$ intensive biotech firms for a sample of pharmaceutical companies, but Fernandez-Bagues (2004) finds a negative correlation between in-house and in-sourced pharmaceutical R\&D projects. Basant and Fikkert (1996) find substitution between $R \& D$ and licensing expenditures for Indian firms, but the findings in Deolikar and Evanson (1989) suggest complementarity. Cassiman and Veugelers (2002) find a positive correlation between the presence of internal $R \& D$ and the adoption of external technology sourcing practices.

\footnotetext{
${ }^{2}$ E.g. the relationship between human resource practices and firm strategies (Ichniowski et al., 1997), and complementarities between the use of information technology and workplace reorganization (Bresnahan et al, 2002), between the adoption of different information technologies in emergency health care (Athey and Stern, 2002), between product and process innovation (Miravete and Pernias, 2004), between public innovation policies (Mohnen and Roller, 2004), and between different types of R\&D cooperation (Belderbos et al, 2006).

${ }^{3}$ Griffith et al. (2004) analyze sectoral productivity growth in OECD countries. They find a significantly greater productivity growth for industries behind the productivity frontier the larger the R\&D expenditures of these industries, suggesting that R\&D facilitates catching up through international knowledge spillovers.
} 
Blonigen and Taylor (2000), on the other hand, find an inverse relationship between R\&D intensity and acquisition activity in high-tech industries, suggesting that firms opt for either a 'make' or a 'buy' strategy. ${ }^{4}$

These contrasting findings could be attributed to several factors. While complementarity is ideally tested directly in an organizational performance ('production function') framework, absence of performance data forced several papers to rely on tests focusing on the 'adoption' of practices, i.e. conditional correlations based on the residuals of reduced form regressions of the practices of interest on a set of observable exogenous variables (Arora and Gambardella, 1990). It has been shown however, (Arora, 1996; Athey and Stern, 1998; Fernandez-Bagues, 2004) that these tests cannot serve, as conclusive evidence of the existence of complementarity as correlation may be the result of unobserved firm characteristics or external shocks that affect the adoption of all practices (Miravete and Pernias, 2004). ${ }^{5}$ Second, several studies had to rely on cross sectional data, such that the estimated impact of innovation practices on firm performance could suffer from endogeneity bias, given the difficulty of instrumenting contemporaneous R\&D properly (e.g. Cassiman and Veugelers, 2002; Veugelers and Cassiman, 1999). Third, studies could often only determine the existence of a practice, but could not identify in detail the intensity with which the practice was implemented by the organization, (e.g. Cassiman and Veugelers, 2002; Fernandez-Bagues, 2004). The extent of complementarity or substitutability between internal R\&D and external R\&D has remained unexplored in the context of a firm performance framework. ${ }^{6}$

In this paper, we contribute the first panel data study exploring complementarity between internal $R \& D$ and external $R \& D$ in a firm performance framework. We examine the impact of internal and external R\&D on labor productivity in a six-year panel of innovating manufacturing firms. We derive our econometric specification from an augmented Cobb Douglas production function including interactions between internal and external R\&D in the augmentation of the knowledge stock. The model also takes into

\footnotetext{
${ }^{4}$ In addition, Audretsch et al. (1996) find evidence of contrasting determinants of internal and external R\&D and suggest that this may imply that the two are substitutes. In contrast, Piga and Vivarelli (2004) find that firms' inhouse R\&D investments increase the propensity to invest in external R\&D.

${ }^{5}$ In addition, one could argue that even in case of robust correlation between practices, there is no guarantee that decision makers were sufficiently well informed such that they indeed chose a combination of practices that optimizes performance.

${ }^{6}$ The exception is Basant and Fikkert (1996), where the analysis is restricted to expenditures on imported licenses in the context of a developing country (India).
} 
account potential productivity convergence by including lagged productivity levels. Our study's inferences are based on a dynamic panel data model, which allows us to control for the existence of unobserved fixed effects that are likely to affect R\&D decisions. Estimation is carried out by several consistent dynamic panel data methods, among which generalized method of moments, which allows for the presence of weakly endogenous explanatory variables. Instead of analyzing the effect of discrete practices or counts of practices, our analysis is of actual expenditures on internal and external R\&D. In this way the analysis can take into account both scale and scope effects of R\&D to address the issue of optimal combinations of these expenditures. Our data are drawn from the R\&D and Community Innovation Surveys among innovating firms in the Netherlands, making this the first comprehensive panel data analysis of the impact of internal and external R\&D for an industrialized country.

The remainder of this paper is organized as follows. The next section details the model and discusses the econometric specification. Section 3 describes the dataset and variable construction. Section 4 presents the empirical results and Section 5 concludes.

\section{Modeling Framework and Econometric Specification}

We derive a modeling framework that allows estimating labor productivity as a function of internal and external R\&D from an augmented Cobb-Douglas production function for firm $i$ at time $t$ :

$Y_{i t}=\alpha L_{i t}^{\beta} C_{i t}^{\delta} K_{i t}^{\gamma} e^{\sigma_{i t}}$

where $\mathrm{Y}$ is output, $\mathrm{L}$ is labor input, $\mathrm{C}$ is the physical capital stock and $\mathrm{K}$ is the knowledge stock. The parameters $\beta, \delta$, and $\gamma$ are elasticities with respect to physical capital, labor and the knowledge stock. The parameter $\sigma$ is firm-specific efficiency parameter. Dividing both sides by labor, taking logarithms 
and differencing the resulting equation in two consecutive periods, we obtain the equation in the growth form:

$\Delta q_{i t}=(\beta-1) \Delta l_{i t}+\alpha \Delta c_{i t}+\gamma \Delta k_{i t}+\Delta \sigma_{i t}$

where $q_{i t}=\log \left(Y_{i t}\right)-\log \left(L_{i t}\right)$ denotes labor productivity, with lower case letters denoting variables in logarithms. We assume that the change in firm-specific efficiency levels is a function of past productivity and an error term, in order to allow for a gradual convergence in efficiency levels between firms. ${ }^{7}$

$\Delta \sigma_{i t}=\theta q_{i t-1}+\varepsilon_{i t}$

Firms that are behind the productivity frontier are more likely to be able to record strong productivity growth through technology spillovers from frontier firms. We expect $\theta$ to fall within the interval $[-1,0]$. If $\theta$ is zero there is no gradual convergence between leading firms and lagging firms; if $\theta$ is -1 complete convergence materializes in one period. To allow unobserved firm-level heterogeneity in efficiency growth and an impact of common macro-economic efficiency shocks, the error term $\varepsilon_{i t}$ in equation (3) includes firm specific fixed effects $\mu_{i}$ and year-specific intercept, $\lambda_{t}$, in addition to serially uncorrelated measurement errors $v_{\mathrm{it}}$ :

$\varepsilon_{i t}=\lambda_{t}+\mu_{i}+v_{i t} \quad$ for $\quad i=1, \ldots, N ; t=1, \ldots, T$

We can transform the knowledge stock portion of the specification (cf. Griffith et al., 2004, p.7; Jones, 2002, p. 233) as follows:

$\gamma \Delta k_{i t} \approx \frac{\partial Y}{\partial K} \frac{K_{t-1}}{Y_{t-1}} \frac{\Delta K}{K_{t-1}} \approx \varphi \frac{\Delta K_{i t}}{Y_{t-1}} \quad$ with $\varphi=\frac{\partial Y}{\partial K}$

\footnotetext{
${ }^{7}$ Klette (1996), for instance, shows that the empirically observed persistent productivity differences between firms require a model specification that allows for gradual convergence.
} 
The change in the knowledge capital stock is assumed to be a function of investments in both internal and external R\&D:

$$
\Delta K_{i t}=f\left(R_{i t-1}^{\mathrm{int}}, R_{i t-1}^{e x t}\right)
$$

We approximate the unknown function (6) with a second-order polynomial in R\&D investment. ${ }^{8}$ If the depreciation rate of the knowledge stock is $\operatorname{small}^{9}$ we can write:

$$
\gamma \Delta k_{i t}=\varphi\left[\eta_{1} R_{i t-1}^{\mathrm{int}}+\eta_{2} R_{i t-1}^{e x t}+\eta_{3}\left(R_{i t-1}^{\mathrm{int}}\right)^{2}+\eta_{4}\left(R_{i t-1}^{e x t}\right)^{2}+\eta_{5} R_{i t-1}^{\mathrm{int}} R_{i t-1}^{\mathrm{int}}\right] / Y_{i t-1}
$$

The equation includes linear terms, quadratic terms, and the interaction term between internal and external R\&D. Although in previous research the quadratic terms have often been suppressed (e.g. Basant and Fikkert, 1996), exclusion of the quadratic terms is certainly not trivial. ${ }^{10}$ There are priori strong reasons to allow for (dis)economies of scale at the same time as testing for (dis)economies of scope. If the process of augmentation of the knowledge capital stock is characterized by declining returns to scale and if high R\&D intensive firms engage in both internal and external $R \& D$, the interaction term between internal and external R\&D may be confounded as negative as it picks up the declining marginal impact of R\&D. Precisely in the presence of declining returns to internal and external R\&D one may expect firms to avoid this by combining R\&D strategies. A full specification with quadratic terms is required to explore this. In the empirical analysis, we will estimate the productivity effects of internal and external R\&D using (6). In

\footnotetext{
${ }^{8}$ Flexible functional forms previously used in the literature can be viewed as linear-in-parameters expansions which approximate an arbitrary function. See Fuss et al. (1978) for known functional forms of such approximations. Adopting a Generalized Leontief Linear functional form (e.g. as in Basant and Fikkert, 1996) gives similar results.

${ }^{9}$ Higher depreciation rates lead to an upward bias of the estimate on the rate of return (Mairesse and Sassenou, 1991). We could expand the approximation of changes in the knowledge stock by including more lags of R\&D; findings in previous studies, e.g. Pakes and Schankerman (1984), Hall et al. (1986) and Klette and Johanson (1998), suggest that the most significant effect of R\&D on productivity occurs with a one-year lag.

10 The rationale for omitting quadratic terms has usually been the difficulty in estimating both the linear and quadratic terms simultaneously given the collinearity between them. Estimation of our model also suffers from this problem, but the availability of panel data reduces this impact.
} 
order to show the importance of using a more general specification, we will also report the results of models with quadratic terms suppressed.

Sufficiently long enough series of capital investments are not available to us in order to construct the capital stock variable with the perpetual inventory method. Instead we approximate the log-growth in the capital stock, $\Delta c_{i t}$ with the log-growth in fixed capital investment. In steady state the proportional change in the capital stock can be approximated by the proportional change in fixed capital investments (Jones, 2002).

Combining equations (2), (3), and (7), writing $\Delta q_{i t}=q_{i t}-q_{i t-1}$ and bringing the lagged productivity term to the right hand side, we arrive at the dynamic panel equation:

$$
\begin{aligned}
q_{i t}= & (1+\theta) q_{i t-1}+(\beta-1) \Delta l_{i t}+\delta \Delta i_{i t}+ \\
& \varphi\left[\eta_{1} R_{i t-1}^{\mathrm{int}}+\eta_{2} R_{i t-1}^{e x t}+\eta_{3}\left(R_{i t-1}^{\mathrm{int}}\right)^{2}+\eta_{4}\left(R_{i t-1}^{e x t}\right)^{2}+\eta_{5} R_{i t-1}^{\mathrm{int}} R_{i t-1}^{\mathrm{int}}\right] / Y_{i t-1}+\lambda_{t}+\mu_{i}+v_{i t}
\end{aligned}
$$

The model allows for firm fixed effects and the persistence of performance differences between firms, both emphasized to be important in the empirical productivity literature (Klette, 1996; Blundell and Bond, 2000).

We carry out the estimation of equation (8) with several panel data estimation techniques that provide consistent estimators, of which several are available when the number of firms $(\mathrm{N})$ is large and the number of years (T) is small. We utilize difference GMM as well as system GMM. For system GMM, the inference based on the asymptotic variance matrix has been found to be more efficient, compared to difference GMM (Arellano and Bover, 1995; Blundell and Bond, 1998). System GMM has also been shown to perform well in the presence of heteroskedasticity in a production function setting with a small time-series dimension. Although recent developments in GMM estimation make it a standard choice for estimation of a dynamic panel data model, it requires a non-trivial decision on the number of instruments. A potential drawback is however that its performance may be unsatisfactory due to weak instruments (Blundell and Bond, 2000). Hence alternatively, we use recently proposed fixed-effects and random- 
effects maximum likelihood estimators (MLE) for dynamic panel data models (Hsiao et al., 2002) based on the transformed likelihood function. The advantage of GMM over MLE estimators is that the former allows for weakly endogenous explanatory variables, while the latter assumes that the explanatory variables are weakly exogenous.

\section{Data}

The empirical analysis makes use annual R\&D surveys in the Netherlands in combination with the Netherlands census of manufacturers, both provided by Statistics Netherlands. The R\&D surveys contain information on type and amount of $R \& D$ expenditures, and the census data contain information on value added, labor, and fixed capital investments. These merged establishment level databases provided us with a balanced panel of 304 manufacturing firms covering the years 1996-2001. The firms are distributed over industries as follows (number of observations in parentheses): Food (34), Textile (9), Paper (15), Printing (5), Petroleum and chemicals (41), Rubber and plastic (19), Metallurgy (5), Metal products (37), Machines \& equipment (62), Electronics (28), Cars and Transport (22), and Miscellaneous industry (27).

The dependent variable, labor productivity, is net value added per employee at constant prices. Internal $R \& D$ is defined as a firm's expenditure on intramural $R \& D$ while external $R \& D$ is the expenditure on contracted R\&D. Investment growth is the percentage growth in gross fixed capital investments between $t-1$ and $t$, and employment growth is the percentage growth in employment.

Table 1 provides descriptive statistics on the variables used in estimation and Table 2 reports propensities (five year means) to engage in external and internal $R \& D$ in five different $R \& D$ intensity classes. An inverse relationship emerges between R\&D intensity and purely in-house R\&D. Almost half of the firms in the lowest $R \& D$ intensity class report only internal $R \& D$, but in the upper $R \& D$ intensity classes $(6 \%$ and more) this number drops to about a third of the firms. On the other hand, the difference in the share of external in total $R \& D$ between the lowest and top intensity classes is not very large. 


\section{Empirical results}

The results of the dynamic panel estimation of equation (8) are reported in Table 3 . The four consistent estimators agree on the signs and magnitudes of most of the coefficients, while the system GMM estimator generates a higher F-value than difference GMM. ${ }^{11}$ The Hansen test of over-identifying restrictions does not reject the validity of the instruments for the GMM models, with the exception of the linear system GMM model in column (2). ${ }^{12}$ Arellano-Bond AR tests also indicate that there are no problems relating to serial correlation of the error terms. The Hausman test, however rejects the random effects MLE in favor of fixed effects.

Columns (1)-(4) of Table 3 present the estimates from a specification restricting $\eta_{3}=\eta_{4}=0$, hence excluding quadratic terms. Internal $R \& D$ is significant in all models, while external $R \& D$ is (marginally) significant in the system GMM model only. The estimated rate of return on the internal R\&D $\left(\varphi \eta_{1}\right)$ is in the range of $0.14-0.30$ depending on the estimator. This rate of return is in line with other studies that use a similar production function framework (Mairesse and Sassenou, 1991, Fors, 1998, Basant and Fikkert, 1996). The rate of return on external R\&D $\left(\varphi \eta_{2}\right)$ in the system GMM model is higher, at 0.82 . The interaction term between internal and external R\&D is insignificant in all models. These results do not support the absorptive capacity hypothesis but equally do not suggest (cf. Basant and Fikkert, 1996; Blonigen and Taylor, 2000; Fernandez-Bagues, 2004) that there are diseconomies of scope in investing in internal and external R\&D simultaneously.

\footnotetext{
${ }^{11}$ GMM results are from the two-step variant of the estimator, which is more efficient than the one-step. The twostep estimates of the standard errors tend to be downward biased (Arellano and Bond 1991; Blundell and Bond 1998). The standard errors are corrected via a finite-sample correction to the two-step covariance matrix derived by Windmeijer (2005). Use of lagged right hand side values as instruments in the difference GMM estimation restricts the panel to 4 years and reduces the number of observations by 304 .

${ }^{12}$ The rejection is at a significance level of 0.08 . Omitting industry dummies from the instrument set does not change this result.
} 
The most efficient (system GMM and MLE fixed effects) estimates for the lagged dependent variable, reflecting movements in and out of equilibrium, indicates a convergence parameter $\theta$ of -0.18 to -0.27 , implying that about a fifth to a fourth of the productivity lead is neutralized by the next period. ${ }^{13}$ The growth of employment and investment variables are positive and significant, the coefficient on labor growth is about $-0.3--0.4$, implying a positive effect of growth on productivity of about $0.6-0.7$, in line with other studies using similar production function framework (e.g. Fors, 1998).

Columns (5) - (8) in Table 3 report the estimates of equation (8) with quadratic terms included, allowing for diseconomies of scale in internal and external R\&D. The different estimation methods produce fairly close estimates. Overall the results clearly suggest that there are diseconomies of scale in both internal and external R\&D with the squares term of both internal and R\&D negative and significant. Furthermore, while the estimated coefficients for the linear term of internal R\&D are large and significantly positive, the coefficients of the linear term of external R\&D are insignificant in all models. On the other hand, allowing for diseconomies of scale leads to substantially higher and significantly positive estimates for the coefficient of the interaction term between internal and external R\&D. The exception in these results is the MLE fixed effects model, which produces smaller and insignificant coefficients for the square term of external $R \& D$ and the interaction term between internal and external R\&D. Overall, the results provide evidence for the existence of economies of scope in combining both types of R\&D. This supports the notion of the importance of absorptive capacity (e.g. Griffith et al. 2004) and suggests that a prerequisite for benefiting from external $R \& D$ is that the firm undertakes in-house R\&D.

To illustrate the impact of internal and external R\&D on labor productivity, Figure 1 plots value added per employee as a function of internal and external R\&D intensity based on the estimated coefficients in the system GMM equation. The figure plots labor productivity for a broad range of internal R\&D $(0-0,4)$ and external $R \& D(0-0,2)$, but it should be noted that the larger majority of firms $(80$

\footnotetext{
${ }^{13}$ Other research (e.g. Blundell and Bond, 2000; Klette, 1996) using GMM techniques find similar values for the lagged productivity term in production function equations.
} 
percent) has R\&D intensities in the 0,1-0,1 range. The figure illustrates that an allocation that sets one type of $R \& D$ to zero and maximizes the other is not optimal. At low levels of internal R\&D intensity (internal R\&D expenditures over value added), an increase in external R\&D intensity (external R\&D over value added) has a relatively small impact on productivity. Productivity levels increase initially steeper along the 'internal' $R \& D$ axis, followed by a yet steeper increase if $R \& D$ is allocated in the 'external' direction. Hence, conditional on a sufficient level of internal R\&D firm can achieve higher productivity gains by switching from a purely internal R\&D strategy to a combination with external R\&D. If external R\&D is increased further, diseconomies of scale start to reduce its marginal impact on productivity. Higher values of internal R\&D intensity allow firms to benefit most from increases in external R\&D.

Figure 1. Labor productivity as a function of internal and external R\&D intensity (estimates of model 6 in Table 3)

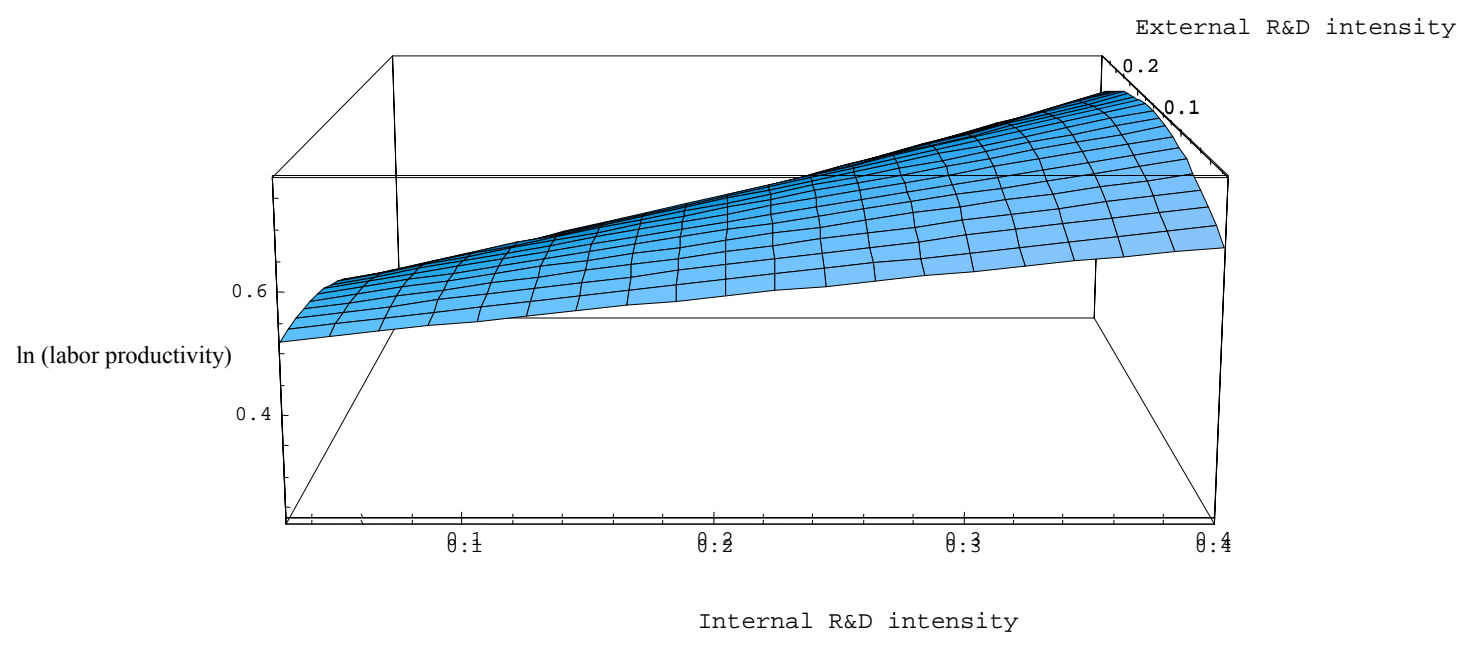




\section{Conclusions}

This paper has produced micro-level econometric evidence that there are productivity gains for firms combining internal and external $R \& D$ strategies. Using a dynamic panel data model derived from an augmented production function framework, our analysis of labor productivity in a sample of 304 innovating firms in the Netherlands during 1996-2001 revealed complementarity between internal and external R\&D in combination with decreasing returns to scale for both internal and external R\&D. A positive impact of external $R \& D$ was only found conditional on a sufficient level of internal $R \& D$ expenditures. These findings support the notion of a dual role played by internal R\&D emphasized in recent research (e.g. Griffith et al. 2004). The first role of in-house research and development activity is in stimulating innovation and productivity. The second role, no less important, is its role to enhance absorptive capacity of the firm needed to derive benefits from the externally acquired R\&D. The findings were robust across a number of dynamic panel data estimation techniques. In contrast, a linear variant of the dynamic model that does not allow for decreasing returns to scale in R\&D did not produce clear evidence of economies of scope in combining internal and external R\&D. These results suggest that empirical studies examining complementarities between continuously measured practices should adopt more general non-linear specifications to allow for correct inferences. ${ }^{14}$

The model presented in this paper assumed constant parameter values across manufacturing industries. A more refined analysis that allows rates of return on R\&D to differ across individual industries could not be performed due to the limited number of observations per industry in our sample. This issue could be tackled in the near future as longer times series of data drawn from $R \& D$ and Innovation surveys become available. Another interesting avenue for future research is the impact on performance of the technological diversity and coherence (e.g. Nesta and Saviotti, 2005) of in-house and outsourced R\&D activities. Despite the need for further extensions, we believe the analysis presented in

\footnotetext{
${ }^{14}$ In addition, our findings suggest caution in interpreting a negative interaction term in a linear model as decisive evidence against complementarity (e.g. Basant and Fikkert, 1996).
} 
the paper serves as a tractable contribution to our understanding of the impact of internal and external R\&D on firm-level productivity. 


\section{References}

Arellano, Manuel and Olympia Bover, 1995, Another look at the instrumental variable estimation of errorcomponents models. Journal of Econometrics, 68, 29-51.

Arora, Ashish and Alfonso Gambardella. 1990. Complementarity and external linkages: the strategies of the large firms in biotechnology. Journal of Industrial Economics 38, 361-79.

Arora, Ashish, 1996, Testing for complementarities in reduced form regressions. Economics Letters, 50, $51-55$.

Athey, S. and S. Stern. 1998. An empirical framework for testing theories about complementarity in organizational design. NBER working paper \#6600.

Athey, S. and S. Stern. 2002. The impact of information technology on emergency health care outcomes. RAND Journal of Economics 33(3), 399-432

Audretsch, David, Albert Menkveld and Roy Thurik, 1996, The decision between internal and external R\&D. Journal of Institutional and Theoretical Economics, 152(3), 519-530.

Basant, Rakesh and Brian Fikkert, 1996, The effects of R\&D, foreign technology purchase, and domestic and international spillovers on productivity in Indian firms. Review of Economics \& Statistics, 78(2), 187199

Bönte, Werner, 2003, R\&D and productivity: internal vs. external R\&D - evidence from West German manufacturing industries. Economics of Innovation and New Technology, 12(4), 343-360. 
Belderbos, René, Martin Carree, and Boris Lokshin, 2004, R\&D Cooperation and Firm Performance, Research Policy, 33 (10), 1477-1492, 2004.

Belderbos, René, Boris Lokshin and Martin Carree, 2006, Complementarity in R\&D Cooperation Strategies, Review of Industrial Organization, forthcoming.

Blonigen, Bruce and Christopher Taylor, 2000, R\&D intensity and acquisitions in high-technology industries: evidence from the US electronic and electrical equipment industries. The Journal of Industrial Economics, 48, 47-70.

Blundell, Richard and Stephen Bond, 2000, GMM estimation with persistent panel data: an application to production functions. Econometrics Reviews, 19(3), 321-340.

Blundell, Richard and Stephen Bond, 1998, Initial conditions and moment restrictions in dynamic panel data models, Journal of Econometrics, 87, 115-143.

Bresnahan, T., E. Brynjolfsson, and L. M. Hit, 2002, Information Technology, Workplace Organization, and the Demand for Skilled Labor: Firm-Level Evidence, Quarterly Journal of Economics 117, Feb 2002, $339-375$.

Cassiman, Bruno and Reinhilde Veugelers, 2002, Complementarity in the innovation strategy: internal R\&D and external technology sourcing, CEPR Discussion Paper 3284, CEPR, London.

Cohen, Wesley and David Levinthal, 1989, Innovation and Learning: two faces of R\&D, Economic Journal 99, 569-596. 
Deolalikar, Anil B, Evenson, Robert E., 1989, Technology production and technology purchase in Indian industry: an econometric analysis. Review of Economics \& Statistics, 71(4), 687-93

Fernandez-Bagües, Manuel, 2004, Complementarity in innovation strategies: evidence from pharmaceutical dynamic panel data. Paper presented at the $30^{\text {th }}$ EARIE conference in Helsinki.

Fors, G., 1996, Utilization of R\&D Results in the Home and Foreign Plants of Multinationals, Journal of Industrial Economics, 45, 3, 341-358.

Fuss, Melvyn, Daniel McFadden, and Yair Mundlak, 1978, A survey of functional forms in the economic analysis of production, in M. Fuss and D. McFadden (eds.), Production Economics: a dual approach to theory and applications, Vol. 1, Amsterdam: North-Holland, 219-268.

Griffith, Rachel, Stephen Redding, and John van Reenen, 2003, R\&D and absorptive capacity: theory and empirical evidence. Scandinavian Journal of Economics, 105(1), 99-118.

Griffith Rachel, Stephen Redding, John Van Reenen, 2004, Mapping The Two Faces Of R\&D: Productivity Growth In A Panel Of OECD Industries, Review of Economics and Statistics, 86(4), 883895.

Griliches, Zvi, 1979, Issues in assessing the contribution of Research and Development to productivity growth, Bell Journal of Economics, 10, 92-116.

Hall, Bronwyn H., Zvi Griliches, and Jerry Hausman, 1986, Patents and R\&D: is there a lag? International Economic Review, 27(2), 265-83. 
Hsiao, C., Pesaran, H. and Tahmiscioglu A. (2002) Maximum likelihood estimation of fixed effects dynamic panel data models covering short time periods, Journal of Econometrics, 109, 107-150.

Ichniowski, C., K. Shaw, and G. Prennushi. 1997. The effects of human resource management practices on productivity. American Economic Review 87: 291-313.

Jones, Charles, 2002, Sources of U.S. economic growth in a world of ideas, American Economic Review, 92(1), 220-239.

Klette, Tor Jacob, and Frode Johansen, 1998, Accumulation of R\&D capital and dynamic firm performance: a not-so-fixed effect model. Annales d'Économie et de Statistique, 49/50, 389-419.

Klette, Tor Jacob, 1996, R\&D, scope economies and plant performance, The RAND Journal of Economics 27(3), 502- 522.

Mairesse, Jacques and Mohammed Sassenou, 1991, R\&D and productivity: a survey of econometric studies at the firm level, NBER working paper No 3666, Cambridge, MA.

Miravete, Eugenio and Jose Pernias, 2004, Innovation Complimentarity and Scale of Production, CEPR Discussion Paper No. 4483, CEPR, London.

Mohnen, Pierre and Lars-Hendrik. Röller (2005) 'Complementarities in innovation policy', European Economic Review, v. 49(6), 1431-50. 
Nesta, Lionel and Pier Saviotti, 2005, Coherence of the knowledge base and the firm's innovative performance: evidence from the U.S. pharmaceutical industry, Journal of Industrial Economics, 53(1), $123-42$.

Pakes, Ariel and Mark Schankerman, 1984, The rate of obsolescence of patents, research gestation lags, and the private rate of return to research resources, in Z. Grilliches (eds.) R\&D, Patents, and Productivity, pp. 73-88, University of Chicago Press

Piga, Caludio, and Marco Vivarelli, 2004, Internal and external R\&D: a sample selection approach. Oxford Bulletin of Economics and Statistics, 66(4), 457-482.

Veugelers, Reinhilde and Bruno Cassiman, 1999, Make and buy in innovation strategies: evidence from Belgian manufacturing firms. Research Policy, 28, 63-80.

Windmeijer, Frank, 2005, A finite sample correction for the variance of linear efficient two-step GMM estimators, Journal of Econometrics, 126, 25-51. 


\section{Table 1 Descriptive statistics}

\begin{tabular}{|c|c|c|c|}
\hline Variable & Mean & S.D. & Description \\
\hline Productivity & 3.92 & 0.48 & $\begin{array}{l}\text { Net value added divided by employees in constant prices, } \\
\text { in logarithm }\end{array}$ \\
\hline$\Delta$ Labor & 0.02 & 0.19 & Log growth in the number of employees \\
\hline$\Delta$ Investment & 0.01 & 3.88 & Log growth in Fixed Capital Investment in constant prices \\
\hline $\mathrm{R}_{\mathrm{DINT}}{ }^{\mathrm{int}}$ & 0.09 & 0.11 & Expenditure on in-house R\&D divided by net value added \\
\hline $\mathrm{R}_{\mathrm{NDINT}}^{\mathrm{ext}}$ & 0.02 & 0.01 & $\begin{array}{l}\text { Expenditure on contracted R\&D divided by net value } \\
\text { added }\end{array}$ \\
\hline
\end{tabular}

Table 2 Internal and External R\&D by R\&D intensity

\begin{tabular}{llll}
\hline R\&D intensity & $\begin{array}{l}\text { Number of } \\
\text { observations }\end{array}$ & $\begin{array}{l}\text { Percentage } \\
\text { internal R\&D } \\
\text { only }\end{array}$ & $\begin{array}{l}\text { Average share of } \\
\text { external in total } \\
\text { R\&D (in \%) }\end{array}$ \\
\hline$<=3 \%$ & 525 & 47.2 & 12.5 \\
$3 \%-6 \%$ & 352 & 49.3 & 9.5 \\
$6 \%-9 \%$ & 199 & 38.2 & 10.7 \\
$9 \%-12 \%$ & 120 & 40.8 & 10.3 \\
$>=12 \%$ & 324 & 25.9 & 15.3 \\
\hline
\end{tabular}


Table 3: Dynamic Panel Data Estimates of Equation (8)

\begin{tabular}{|c|c|c|c|c|c|c|c|c|}
\hline & $\begin{array}{l}\text { GMM } \\
\text { (difference) }\end{array}$ & $\begin{array}{l}\begin{array}{l}\text { GMM } \\
\text { (system) }\end{array} \\
\end{array}$ & $\begin{array}{l}\text { MLE } \\
\text { FE }\end{array}$ & $\begin{array}{l}\text { MLE } \\
\text { RE }\end{array}$ & $\begin{array}{l}\text { GMM } \\
\text { (difference) }\end{array}$ & $\begin{array}{l}\text { GMM } \\
\text { (system) }\end{array}$ & $\begin{array}{l}\text { MLE } \\
\text { FE }\end{array}$ & $\begin{array}{l}\text { MLE } \\
\text { RE }\end{array}$ \\
\hline & $(1)$ & $(2)$ & (3) & $(4)$ & (5) & (6) & (7) & (8) \\
\hline Productivity $_{-1}$ & $\begin{array}{l}0.581^{* * * *} \\
(0.117)\end{array}$ & $\begin{array}{l}0.823 * * * \\
(0.059)\end{array}$ & $\begin{array}{l}0.719 * * * \\
(0.060)\end{array}$ & $\begin{array}{l}0.522 * * * \\
(0.042)\end{array}$ & $\begin{array}{l}0.628^{* * *} \\
(0.128)\end{array}$ & $\begin{array}{l}0.762^{* * * *} \\
(0.062)\end{array}$ & $\begin{array}{l}0.813 * * * \\
(0.055)\end{array}$ & $\begin{array}{l}0.494 * * * \\
(0.038)\end{array}$ \\
\hline$\Delta$ Labor & $\begin{array}{l}-0.361 * * * \\
(0.057)\end{array}$ & $\begin{array}{l}-0.424 * * * \\
(0.060)\end{array}$ & $\begin{array}{l}-0.381 * * * \\
(0.042)\end{array}$ & $\begin{array}{l}-0.334 * * * \\
(0.037)\end{array}$ & $\begin{array}{l}-0.408 * * * \\
(0.068)\end{array}$ & $\begin{array}{l}-0.401 * * * \\
(0.058)\end{array}$ & $\begin{array}{l}-0.432 * * * \\
(0.043)\end{array}$ & $\begin{array}{l}-0.338^{* * *} \\
(0.036)\end{array}$ \\
\hline$\Delta$ investment & $\begin{array}{l}0.009^{*} \\
(0.005)\end{array}$ & $\begin{array}{l}0.010^{* *} \\
(0.005) \\
\end{array}$ & $\begin{array}{l}0.009^{*} \\
(0.005)\end{array}$ & $\begin{array}{l}0.008^{*} \\
(0.004) \\
\end{array}$ & $\begin{array}{l}0.008^{*} \\
(0.004)\end{array}$ & $\begin{array}{l}0.011^{*} \\
(0.006)\end{array}$ & $\begin{array}{l}0.008^{*} \\
(0.004)\end{array}$ & $\begin{array}{l}0.007^{*} \\
(0.004)\end{array}$ \\
\hline R\&DINT $^{\text {int }}$ & $\begin{array}{l}0.304 * * \\
(0.112)\end{array}$ & $\begin{array}{l}0.299^{* *} \\
(0.129) \\
\end{array}$ & $\begin{array}{l}0.307 * * * \\
(0.053)\end{array}$ & $\begin{array}{l}0.137 * * * \\
(0.042)\end{array}$ & $\begin{array}{l}1.318^{* * * *} \\
(0.466)\end{array}$ & $\begin{array}{l}0.432 * * \\
(0.194)\end{array}$ & $\begin{array}{l}1.229 * * * \\
(0.194)\end{array}$ & $\begin{array}{l}0.230^{* *} \\
(0.125)\end{array}$ \\
\hline R\&DINT $^{\text {int }}$ squared & & & & & $\begin{array}{l}-0.182 * * * \\
(0.069)\end{array}$ & $\begin{array}{l}-0.050^{*} \\
(0.027)\end{array}$ & $\begin{array}{l}-0.166^{* * *} \\
(0.031)\end{array}$ & $\begin{array}{l}-0.041^{* *} \\
(0.020)\end{array}$ \\
\hline $\mathrm{R}^{2} \mathrm{DINT} \mathrm{e}^{\mathrm{ext}}$ & $\begin{array}{l}0.602 \\
(0.690) \\
\end{array}$ & $\begin{array}{l}0.819^{*} \\
(0.483) \\
\end{array}$ & $\begin{array}{l}0.297 \\
(0.368)\end{array}$ & $\begin{array}{l}0.188 \\
(0.271) \\
\end{array}$ & $\begin{array}{l}0.994 \\
(0.749) \\
\end{array}$ & $\begin{array}{l}0.126 \\
(0.615)\end{array}$ & $\begin{array}{l}0.461 \\
(0.397) \\
\end{array}$ & $\begin{array}{l}0.201 \\
(0.298) \\
\end{array}$ \\
\hline R\&DINT $^{\text {ext }}$ squared & & & & & $\begin{array}{l}3.486^{*} \\
(1.893)\end{array}$ & $\begin{array}{l}-3.466^{* * *} \\
(1.295)\end{array}$ & $\begin{array}{l}-1.736 \\
(1.160) \\
\end{array}$ & $\begin{array}{l}2.530^{* * *} \\
(0.977)\end{array}$ \\
\hline $\mathrm{R}^{2} \mathrm{DINT}^{\mathrm{int}} * \mathrm{R}^{\prime} \& \mathrm{DINT}^{\mathrm{ext}}$ & $\begin{array}{l}0.142 \\
(0.251)\end{array}$ & \begin{tabular}{|l|}
0.061 \\
$(0.164)$
\end{tabular} & $\begin{array}{l}0.004 \\
(0.155)\end{array}$ & $\begin{array}{l}0.064 \\
(0.121)\end{array}$ & $\begin{array}{l}2.004 * \\
(1.207)\end{array}$ & $\begin{array}{l}2.581 * * * \\
(0.801)\end{array}$ & $\begin{array}{l}0.862 \\
(0.753)\end{array}$ & $\begin{array}{l}1.668 * * * \\
(0.634)\end{array}$ \\
\hline Wald(df) /LL & 162.57 & 547.75 & -82.33 & -332.96 & 345.68 & 353.84 & -57.01 & -314.35 \\
\hline Hansen test (df), p-value & $\begin{array}{l}16.11(20) \\
(0.71)\end{array}$ & $\begin{array}{l}50.50(34) \\
(0.08)\end{array}$ & & & $\begin{array}{l}14.90(21) \\
(0.83)\end{array}$ & $\begin{array}{l}35.34(27) \\
(0.13)\end{array}$ & & \\
\hline AR(1) test (p-value) & $-4.96(0.00)$ & $-6.98(0.00)$ & & & $-4.63(0.00)$ & $-6.95(0.00)$ & & \\
\hline $\mathrm{AR}(2)$ test (p-value) & $-0.32(0.75)$ & $0.20(0.84)$ & & & $-0.09(0.93)$ & $0.21(0.83)$ & & \\
\hline N. Obs. & 1216 & 1520 & 1216 & 1520 & 1216 & 1520 & 1216 & 1520 \\
\hline
\end{tabular}

Notes: * significant at $10 \%$; ** significant at $5 \%$; ** significant at $1 \%$. System GMM and MLE random effects models include industry dummies. A11 models include year dummies. Instruments for the difference GMM equations are industry dummies and lagged values of the right hand side variables; the extra lag restricts the panel to 4 years and reduces the number of observations by 304 . Instruments for the level equations are industry dummies and differenced values of the right hand side variables. Robust standard errors are in parentheses. For GMM estimates, the finite-sample correction to the two-step covariance matrix derived by Windmeijer (2005) is used. The Hausman test of random vs. fixed effects MLE is $33.4 \quad(p<0.001)$ and 69.4 ( $p<0.001)$ for the 1inear and quadratic mode1s, respectively. Estimation of GMM is carried out with the xtabond2 Stata 9.0 module by D. Roodman, Center for Global Development, Washington. Estimation of MLE is carried out with SAS/IML. 